\title{
Imaging in the Assessment of Musculoskeletal Manifestations Associated with Inflammatory Bowel Disease
}

\author{
Andrea Becciolini * ${ }^{\mathbb{C}}$, Eleonora Di Donato, Gianluca Lucchini, Daniele Santilli $\mathbb{1}$, Flavio Mozzani, Michele Riva \\ and Alarico Ariani \\ Unit of Internal Medicine and Rheumatology, Department of Medicine, Azienda Ospedaliero-Universitaria di \\ Parma, 43126 Parma, Italy; eleonoradidonato@ymail.com (E.D.D.); glucchini@ao.pr.it (G.L.); \\ dsantilli@ao.pr.it (D.S.); fmozzani@ao.pr.it (F.M.); mriva@ao.pr.it (M.R.); dott.alaricoariani@libero.it (A.A.) \\ * Correspondence: beccio@yahoo.it or becciolini@ao.pr.it
}

check for updates

Citation: Becciolini, A.; Di Donato,

E.; Lucchini, G.; Santilli, D.; Mozzani,

F.; Riva, M.; Ariani, A. Imaging in the

Assessment of Musculoskeletal

Manifestations Associated with Inflammatory Bowel Disease.

Gastroenterol. Insights 2021, 12,

100-110. https://doi.org/10.3390/

gastroent12010010

Academic Editor: Rinaldo Pellicano

Received: 2 February 2021

Accepted: 18 March 2021

Published: 21 March 2021

Publisher's Note: MDPI stays neutral with regard to jurisdictional claims in published maps and institutional affiliations.

Copyright: (C) 2021 by the authors Licensee MDPI, Basel, Switzerland. This article is an open access article distributed under the terms and conditions of the Creative Commons Attribution (CC BY) license (https:// creativecommons.org/licenses/by/ $4.0 /)$.
Abstract: Extraintestinal manifestations are the cause of morbidity and affect the quality of life of patients with inflammatory bowel diseases (IBDs). Musculoskeletal manifestations, in particular, spondyloarthritis and osteoporosis, are the most frequent extraintestinal manifestation of IBDs. The diagnosis and management of the musculoskeletal manifestation of IBDs relies on imaging. Conventional radiography, magnetic resonance imaging, computed tomography, and ultrasound can help to detect pathological signs of spondyloarthritis, both peripheral and with axial involvement. Dual-energy X-ray absorptiometry is the gold standard for identifying the presence of osteoporosis, whereas conventional radiology and computed tomography can reveal occult vertebral fractures. The aim of this narrative review is to describe the imaging of musculoskeletal manifestations of IBDs.

Keywords: inflammatory bowel disease; spondyloarthritis; osteoporosis; magnetic resonance imaging; ultrasound; computed tomography

\section{Introduction}

Inflammatory bowel diseases (IBDs), a term encompassing ulcerative colitis (UC) and Crohn's disease (CD), affect more than 2 million people in Europe [1]. Extraintestinal manifestations of IBDs are very frequent since more than up to 50\% of patients could experience one [2]. Musculoskeletal manifestations are the most frequent extraintestinal complications of IBDs, and they are an important cause of morbidity and impairment of quality of life [3]. The association between IBD and arthritis has been reported since 1960s [4]; on the other hand, the concept of spondyloarthritis (SpA) and the understanding of its spectrum disorders has significantly advanced only in the last two decades [5]. The most frequent rheumatic manifestations among patients with IBDs are sacroiliitis (from to $2-32 \%$ ); peripheral arthritis, that can be further classified as oligoarticular with large joint involvement (type 1) and bilateral symmetrical polyarthritis (type 2) (from 7-16\%); enthesitis (from 1-54\%); and dactylitis (from 2-4\%) [6]. Axial involvement has been reported more frequently among patients with CD (5-22\%) than in those with UC (2-6\%); on the other hand, there was no association with IBD disease activity [7]. Type 1 peripheral arthritis affects mainly CD patients with a colonic localization and is strongly associated with other extraintestinal manifestations (such as erythema nodosum and uveitis) and disease activity [6]. Furthermore, osteoporosis affects about $24 \%$ of IBD patients [8]. Table 1 summarizes the musculoskeletal manifestations of IBDs. 
Table 1. Musculoskeletal manifestations of inflammatory bowel diseases (IBDs).

\begin{tabular}{|c|c|c|}
\hline & Clinical Features & Affected Sites \\
\hline \multicolumn{3}{|l|}{ Peripheral arthritis } \\
\hline Type 1 & $\begin{array}{l}\text { - Acute and self-limiting attacks of joint pain } \\
\text { and swelling } \\
\text { - Usually associated with other extraintesinal } \\
\text { manifestations and IBDs exacerbation } \\
\text { - } \quad \text { Last less than } 10 \text { weeks } \\
\text { No permanent articular damage }\end{array}$ & $\begin{array}{l}\text { - Oligoarticular (less than } 5 \text { joints) asymmetric } \\
\text { involvement that prevalently affects large } \\
\text { weight-bearing joints }\end{array}$ \\
\hline Type 2 & $\begin{array}{l}\text { - } \quad \text { Chronic joint pain and swelling } \\
\text { - } \quad \text { Persistent (months to years) } \\
\text { Usually associated with other extraintestinal } \\
\text { manifestations }\end{array}$ & $\begin{array}{l}\text { - Polyarticular symmetric involvement that } \\
\text { prevalently affect small joints }\end{array}$ \\
\hline Enthesitis & $\begin{array}{l}\text { - Pain and swelling affecting the insertion of } \\
\text { tendons or ligaments into bones }\end{array}$ & - Usually affects weight bearing entheses \\
\hline Dactylitis & $\begin{array}{l}\text { - Pain and diffuse swelling (sausage-like) } \\
\text { affecting fingers or toes }\end{array}$ & - $\quad$ Fingers and/or toes \\
\hline Axial involvement & $\begin{array}{l}\text { - Inflammatory back pain associated with } \\
\text { morning stiffness }\end{array}$ & - Sacroiliac joints and/or the spine \\
\hline Osteoporotic fracture & $\begin{array}{l}\text { - Pain at the affected bone (can be } \\
\text { asymptomatic) }\end{array}$ & - $\quad$ Any bone (in particular hip and vertebrae) \\
\hline
\end{tabular}

The main purpose of this narrative review is to describe the imaging of musculoskeletal manifestations of IBDs.

\section{Imaging in the Assessment of Inflammatory Musculoskeletal Manifestations}

Imaging has a pivotal role in the assessment of inflammatory musculoskeletal manifestations of IBDs. The use of noninvasive and reproducible techniques, such as ultrasound (US), magnetic resonance imaging (MRI), computed tomography (CT), and conventional radiography, can help the clinician to detect early pathological manifestation in order to achieve a correct diagnosis and treat the patient accordingly. The structures involved in inflammatory musculoskeletal manifestations of IBDs are peripheral and axial joints, vertebral bodies, tendons, and entheses. Joint inflammation is characterized by synovitis and subchondral osteitis that can lead to erosion, new bone formation, sclerosis and, in the case of sacroiliac joints, to ankylosis. Similarly, vertebral body inflammation, characterized by subchondral osteitis, can lead to erosion, sclerosis, and syndesmophytes. Tendon with sheath inflammation is characterized by tenosynovitis. Enthesis inflammation is characterized by insertional tendon thickening, neoangiogenesis, and bursitis that can lead to erosion and new bone formation [9]. Table 2 summarizes the role of imaging techniques in the assessment of inflammatory musculoskeletal manifestations of IBDs. 
Table 2. Imaging techniques in the assessment of inflammatory musculoskeletal manifestations of IBDs.

\begin{tabular}{|c|c|c|c|c|}
\hline Imaging Techniques & Structures Assessed & Pathological Findings & Advantages & Disadvantages \\
\hline $\begin{array}{l}\text { Conventional } \\
\text { radiography }\end{array}$ & $\begin{array}{l}\text { Peripheral joints } \\
\text { Axial joints } \\
\text { Vertebral bodies } \\
\text { Entheses }\end{array}$ & $\begin{array}{c}\text { Erosion, vertebral } \\
\text { syndesmophyte, } \\
\text { sclerosis, ankylosis, } \\
\text { new bone formation }\end{array}$ & $\begin{array}{l}\text { Low cost, reference } \\
\text { technique, short testing } \\
\text { time, wide availability, } \\
\text { baseline assessment }\end{array}$ & $\begin{array}{l}\text { Ionizing radiation, } \\
\text { limited in detection of } \\
\text { inflammatory lesions, } \\
\text { low sensitivity } \\
\text { High cost, limited }\end{array}$ \\
\hline $\begin{array}{c}\text { Magnetic resonance } \\
\text { imaging }\end{array}$ & $\begin{array}{l}\text { Peripheral joints } \\
\text { Axial joints } \\
\text { Vertebral bodies } \\
\text { Tendon } \\
\text { Entheses }\end{array}$ & $\begin{array}{c}\text { Bone marrow edema, } \\
\text { synovitis, } \\
\text { tenosynovitis, } \\
\text { enthesitis, bursitis, } \\
\text { erosion }\end{array}$ & $\begin{array}{l}\text { Sensitive, no radiation } \\
\text { burden, high spatial } \\
\text { resolution, excellent } \\
\text { soft tissue visualization }\end{array}$ & $\begin{array}{c}\text { availability, long } \\
\text { scanning time, not } \\
\text { dynamic, } \\
\text { contraindicated in } \\
\text { patients with metallic } \\
\text { implants }\end{array}$ \\
\hline Computed tomography & $\begin{array}{l}\text { Peripheral joints } \\
\text { Axial joints } \\
\text { Vertebral bodies } \\
\text { Tendon }\end{array}$ & $\begin{array}{c}\text { Erosion, vertebral } \\
\text { syndesmophyte, } \\
\text { sclerosis, ankylosis, } \\
\text { new bone formation }\end{array}$ & $\begin{array}{l}\text { Sensitive, high spatial } \\
\text { resolution }\end{array}$ & $\begin{array}{l}\text { High cost, limited } \\
\text { availability, ionizing } \\
\text { radiation, no detection } \\
\text { of inflammatory lesions }\end{array}$ \\
\hline Ultrasound & $\begin{array}{c}\text { Peripheral joints } \\
\text { Tendon } \\
\text { Entheses }\end{array}$ & $\begin{array}{c}\text { Synovitis, } \\
\text { tenosynovitis, } \\
\text { enthesitis, erosion, new } \\
\text { bone formation }\end{array}$ & $\begin{array}{l}\text { Sensitive, no radiation } \\
\text { burden, high spatial } \\
\text { resolution, excellent } \\
\text { soft tissue visualization, } \\
\text { short testing time, } \\
\text { bedside procedure }\end{array}$ & $\begin{array}{l}\text { Limited acoustic } \\
\text { windows, operator } \\
\text { dependency, long } \\
\text { learning curve }\end{array}$ \\
\hline
\end{tabular}

\subsection{Conventional Radiography}

Conventional radiography of joints, spine, and pelvis is useful for the assessment of baseline structural changes in patients with SpA. On the other hand, conventional radiography usually depicts later stage modifications and its use could be limited in young patients or in those with short symptom duration [9].

\subsubsection{Sacroiliac Joints}

Sacroiliac joints signs of SpA include sclerosis, erosions, and ankylosing and can be classified, according to the New York criteria, as grade 0 (normal), grade 1 (suspicious changes), grade 2 (minimum abnormality-small localized areas with erosion or sclerosis without alteration in the joint width), grade 3 (unequivocal abnormality-moderate or advanced sacroiliitis with erosions, evidence of sclerosis, widening, narrowing, or partial ankylosis), and grade 4 (severe abnormality - total ankylosis) [10]. Among patients with IBDs, radiological sacroiliitis has been reported in $20-50 \%$ of cases [11-14]. Interestingly, radiographic sacroiliitis can be asymptomatic. Bandinelli et al., in a series of 81 IBD patients without clinical musculoskeletal manifestations, reported that conventional radiography of pelvis showed sacroiliac abnormalities in 22 cases, of which 4 developed inflammatory back pain and active sacroiliitis on MRI during 3 years of follow-up [15].

\subsubsection{Spine}

Typical radiographic spine signs are the squaring of vertebral bodies followed by sclerosis and erosion of the anterior and posterior edges of the vertebral endplates (Romanus lesions) and, finally, the formation of vertebral body fusion by marginal syndesmophytes ("bamboo spine"). The involvement of the spine can be quantified with the modified Stokes Ankylosing Spondylitis Spine Score (mSASSS), a validated scoring system that can assess the progression of disease over time [16].

Spinal involvement, with evidence of syndesmophytes, have been reported in 1-10\% of patients with IBDs [7,17-19].

\subsubsection{Peripheral Joints}

Radiography of peripheral joints can demonstrate soft tissue swelling, erosions, and new bone formation. However, none of the radiographic signs are pathognomonic of 
arthritis due to IBDs. The radiograph of entheses can detect enthesophytes (i.e., abnormal bony spurs at the attachment of the tendon onto bone) and erosions, even if those are usually present only in late-stage disease [19].

\subsection{Magnetic Resonance Imaging}

In the last few decades, the gold standard imaging modality for assessing inflammatory (synovitis, tenosynovitis, enthesitis, and bone marrow edema) and structural (bone erosion, new bone formation, sclerosis, and fat infiltration) changes of joints, tendons, and spine is MRI $[9,20]$.

\subsubsection{Sacroiliac Joint}

According to Assessment of SpondyloArthritis International Society (ASAS) MRI working group [21], typical sacroiliac joint inflammatory findings in SpA include osteitis/bone marrow edema (defined as hypointense signal on T1-weighted images and hyperintense signal on T2-weighted and short tau inversion recovery (STIR) sequences), enthesitis (defined as enthesis thickness and hyperintense signal on T2-weighted and STIR images that can be associated with peri-entheseal soft tissues swelling or edema and adjacent bone marrow edema), capsulitis (defined as thickening of the joint capsule and ligaments associated with a hyperintense signal on T2-weighted or STIR images) and synovitis (defined as hyperintense signal on contrast-enhanced T1-weighted images with fat saturation). MRI can also depict structural damage due to previous inflammation such as subchondral/periarticular erosions, periarticular fat deposition, bony bridges, ankylosis, and subchondral sclerosis. The use of paramagnetic gadolinium as a contrast agent is necessary for detecting sacroiliac synovitis and could help identifying enthesitis and capsulitis; moreover, it can help to distinguish septic and neoplastic alterations [22]. According to ASAS criteria for diagnosis of active sacroiliitis, MRI must depict bone marrow edema on STIR in the subchondral bone marrow (Figure 1), and the presence of any other inflammatory or structural lesion is not mandatory [21].

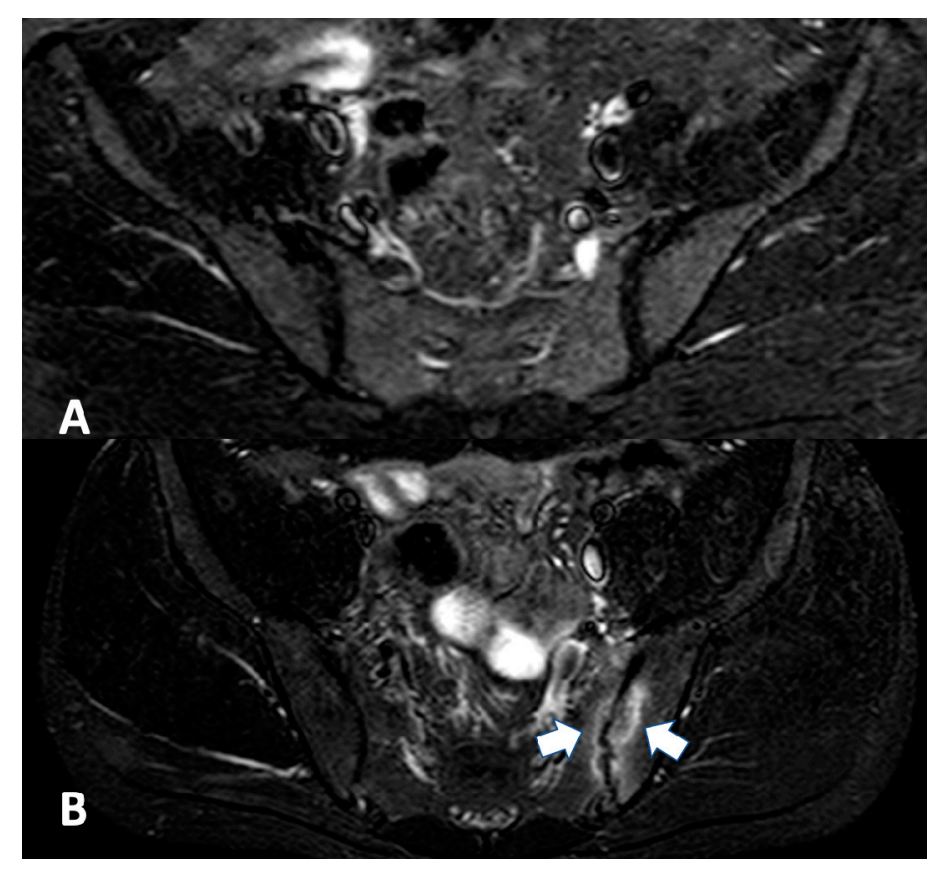

Figure 1. Axial short tau inversion recovery (STIR) sequence MRI of the sacroiliac joints. (A) Normal sacroiliac joints. (B) Subchondral bone marrow hyperintensities involving both iliac and sacral bones on the left side (arrows).

Some studies have reported the prevalence of sacroiliitis among patients with IBDs. A monocentric retrospective French study involving 186 IBD patients undergoing MRI 
enterography or colonography highlighted a prevalence of $16.7 \%$ of sacroiliitis, which was bilateral in 14 cases and unilateral in 17 [23]. A similar monocentric retrospective study involving 286 IBD patients revealed the presence of sacroiliitis in $26(9.1 \%)$ on MRI enterography [24]. A cross-sectional study among 120 Indian IBD patients with sacroiliac involvement by MRI has been depicted in $20 \%$ of cases, three of whom were asymptomatic [25]. Among $44 \mathrm{CD}$ patients with disease duration of 5 to 12 years undergoing pelvis MRI, sacroiliitis was reported in 17 (39\%), 5 of whom had SpA [26]. More recently, a multicentric retrospective Italian study included 894 IBD patients undergoing MRI or CT enterography highlighted the presence of sacroiliitis in 129 cases $(16.4 \%$, of which 89 were from MRI examinations). Interestingly sacroiliac joint alterations were not reported in the majority of examinations (112 [86\%], 78 by MRI) [27]. A pilot study involving 11 IBD patients with arthralgia analyzed by hand MRI revealed, in two cases, the presence of enthesitis [28].

\subsubsection{Spine}

At the level of the spine, active lesions are characterized by small hypointense T1weighted and hyperintense T2- and STIR-weighted sequences of the vertebral body corners or plates. Chronic spine lesions are characterized by areas of fatty bone marrow replacement that appear hyperintense in T1 and T2 MRI sequences at the vertebral body corners or plates. Sclerosis, new bone formation, and ankylosis, characterized by low-intensity signals on all MRI sequences, can be identified in later stages $[9,20]$.

\subsubsection{Entheses and Tendons}

Entheses can be assessed with MRI and is especially useful in the early inflammatory phase showing the presence of thickening that appears hyperintense on T2- and hypointense on T1-weighted images, with peri-entheseal swelling, insertional bone edema, bursitis, and erosions. However, alterations detected by MRI could also be found in noninflammatory diseases such as mechanical induced enthesopathy [9,29]. The hallmark of dactylitis in MRI evaluation are flexor tenosynovitis, extensor tenonitis/paratendinitis, subcutaneous edema and, less frequently, distention of finger joint capsule [9,20].

\subsection{Computed Tomography}

CT can provide very detailed information about structural alterations of bone such as erosion, sclerosis, and ankylosis (Figure 2) [30]. However, differently from MRI, it cannot determine whether the disease is active or not. Furthermore, alterations such as sclerosis could be secondary to disease, different from SpA such as osteitis condensans ilii and diffuse idiopathic skeletal hyperostosis [20].

Since several patients with IBDs undergo CT enterography as part of their clinical workout, it is possible to use this examination for diagnosing SpA.

Many studies have reported the prevalence of sacroiliitis in CT. In a cross-sectional study of 65 IBD patients, CT revealed the presence of asymptomatic sacroiliitis in 21 $(32 \%)$ cases [31]. A similar study of 86 patients with CD sacroiliitis was shown by CT in $25(29 \%)$ [32]. In the Gotler et al. study, a subset of 137 IBD patients underwent CT enterography that highlighted signs of sacroiliitis in 34 (25\%) [24]. An observational study evaluating abdominal CT among 163 Korean IBD patients revealed the presence of sacroiliitis in $27(16.6 \%)$ cases (10/82 [12.2\%] in UC and 17/81 [21\%] in CD) [33]. A further analysis of the study of Leclerc-Jacobs et al. [23] included 51 IBD patients that also underwent abdominal CT, confirming sacroiliitis in 12 (23.5\%) cases, of which 6 had inflammatory low back pain [34]. A retrospective analysis of CT enterography in $221 \mathrm{CD}$ patients revealed sacroiliitis in $53(24 \%)$ cases [35]. Among 80 patients with the same disease undergoing abdominal CT, signs of sacroiliitis were found in $27(33.8 \%)$, more frequently in subjects with inflammatory back pain (19/40) than in those without (8/40) [36]. Interestingly, sacroiliitis was revealed in 4 cases among a control group of 40 patients 
without IBDs and inflammatory back pain. Finally, a recent large retrospective study of 317 IBD patients undergoing abdominal CT identified $49(16 \%)$ cases with sacroiliitis [37].

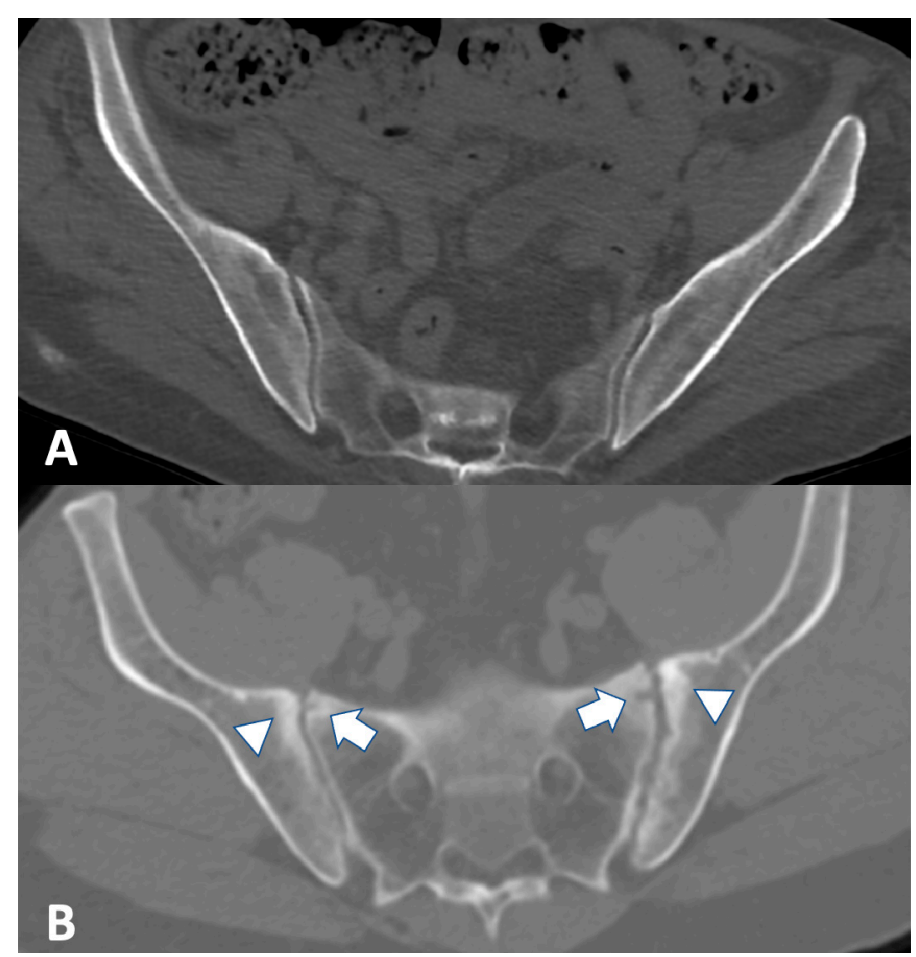

Figure 2. Axial CT image of the sacroiliac joints. (A) Normal sacroiliac joints. (B) Structural changes of sacroiliac joints: bilateral erosions (arrows) and bone sclerosis (arrowheads).

\subsection{Ultrasound}

US is a noninvasive, reproducible technique that is widely diffused in current rheumatology practice. Differently from MRI, ASAS does not include US in the classification criteria for $\mathrm{SpA}$; however, it a very useful technique that can allow real-time recognition of even asymptomatic structural and inflammatory abnormalities of joints, tendon, and entheses, especially in early phases [38]. On the other hand, the main disadvantages of US are represented by its operator dependent nature and the relatively long learning curve.

\subsubsection{Peripheral Joints}

The main joint alterations that can be depicted by gray-scale US examinations are effusion, synovial hypertrophy, bone erosions, and new bone formation. On top of that, the use of US with color and power Doppler can reveal synovial neoangiogenesis, an indicator of inflammation that can be applied in diagnosis and follow-up of SpA in clinical practice [39]. Joint US scoring methods are inherited by rheumatoid arthritis [40].

\subsubsection{Entheses and Tendons}

Gray-scale US tendon examination can depict alterations such as loss of fibrillar echogenicity, hypoechoic thickening, bone erosions, or new bone formations. For tendons with sheath, tenosynovial effusion and hypertrophy can be highlighted. US with color and power Doppler can reveal synovial and entheseal neoangiogenesis [39]. Dactylitis, that is, tenosynovitis of the fingers and toes characteristic of $\mathrm{SpA}$, and enthesitis can be depicted by US (Figure 3). Entheses US scoring methods such as the Glasgow ultrasound enthesitis scoring system (GUESS) [41] or the Madrid sonography enthesitis index (MASEI) [42] have been developed. 


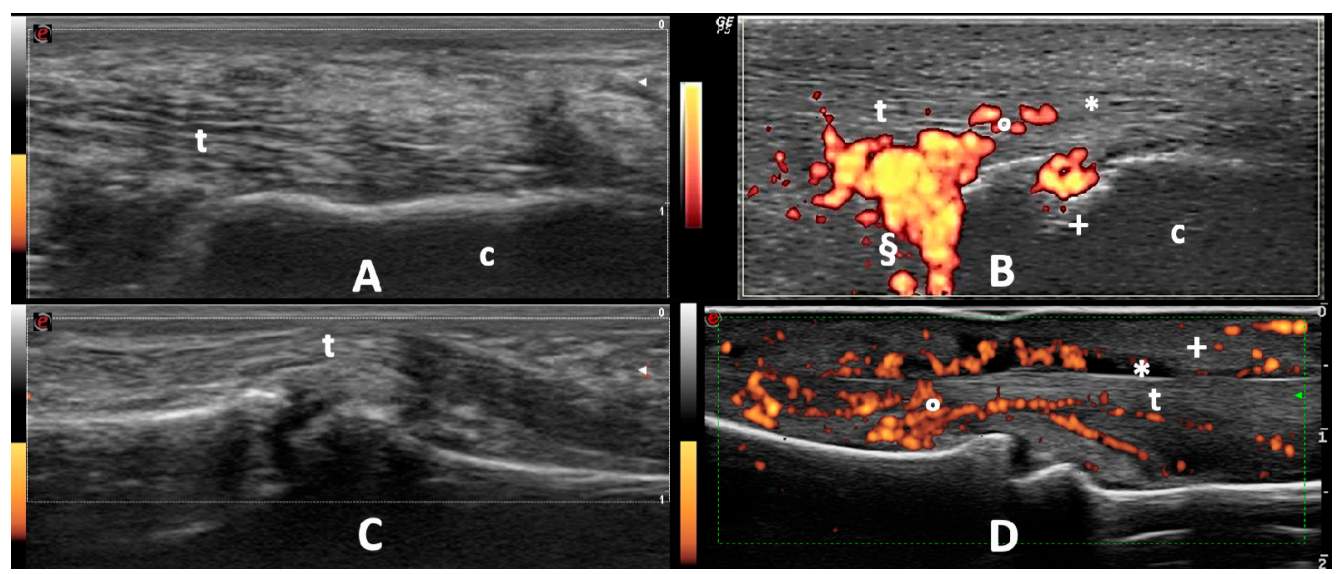

Figure 3. Ultrasound examinations. (A) Normal Achilles tendon (t) insertion on the calcaneus (c). (B) Achilles enthesitis characterized by tendon hypoechogenicity $\left({ }^{*}\right)$, hypervascularization $\left({ }^{\circ}\right)$, erosion $(+)$, and deep retrocalcaneal bursitis $(\S) .(\mathbf{C})$ Normal flexor tendons (t) of the II finger. (D) Dactylitis characterized by tenosynovitis $(*)$, hypervascularization $\left(^{\circ}\right)$, and swelling of the subcutaneous tissue $(+)$.

Different studies have evaluated the role of ultrasound in detecting US entheseal abnormalities among IBD patients. An Italian cross-sectional study involving 81 IBD patients without musculoskeletal symptoms revealed gray-scale lower limb entheseal alterations in $71(92.6 \%)$ cases and a positive power Doppler in $13(16 \%)$ [43]. A multicenter cross-sectional study of IBDs 76 patients highlighted that $64(84.1 \%)$ had at least one grayscale entheseal alteration, 11 (13.9\%) one entheseal positive power Doppler, and $32(42.1 \%)$ sub-clinical joint involvement [44]. A Turkish monocentric cross-sectional study including 43 IBDs, 44 celiac patients and 18 healthy controls found higher entheseal gray-scale and power Doppler US alterations in the two pathological groups [45]. Since fibromyalgia, a condition characterized by widespread non-inflammatory pain, could be associated with IBDs the value of US has been assessed in this setting. A recent multicenter cross-sectional study found that patients with IBDs and SpA had higher MASEI score than those with IBDs and fibromyalgia [46]. Finally, a multicenter cross-sectional study including 148 IBD patients revealed gray-scale entheseal involvement in $87.8 \%$ of cases, with positive entheseal power Doppler in 29.7\% [47].

\section{Imaging in the Assessment of Non-Inflammatory Musculoskeletal Manifestation}

Patients with IBD have an increased risk of developing osteopenia and osteoporosis, respectively defined by the World Health Organization as between -1 to -2.5 and less than or equal to -2.5 standard deviation bone mineral density than the general population (T-score) by dual-energy X-ray absorptiometry (DEXA). Factors involved in development of osteoporosis among patients with IBDs are usually related to chronic inflammation, cumulative corticosteroid dose, disease duration, age, diffuse bowel disease or ileal resection, alcohol consumption, smoking, low physical activity, low calcium intake, and sarcopenia [48]. Osteoporosis is a silent disease because no signs or symptoms are associated with bone loss. Furthermore, almost two-thirds of vertebral fractures, the most frequent complication of osteoporosis, are not symptomatic (Figure 4) [49].

On the other hand, femoral fracture could be associated with mortality up to $10 \%$ at one month and up to $30 \%$ at one year [50]; therefore, osteoporosis screening and treatment is mandatory.

Among IBD patients, a prevalence of osteopenia ranging from 32 to $50 \%$ and of osteoporosis from 5 to $37 \%$ have been reported in several studies [8,51-54]. Interestingly, Reffitt et al. [55] have observed that bone mineral density improves with long-lasting stable remission; IBDs, however, appear to be associated with vertebral fractures independently of DEXA values [56]. In particular, IBD patients have a significantly higher risk of vertebral fractures, but not that of other sites, when compared to healthy controls ( $\mathrm{OR}=2.26,95 \%$ CI 1.04-4.09) [57]. 
Abdominal CT obtained for other indications could be used to measure lumbar spine bone mineral density [58] and is also capable of clearly identifying vertebral fractures.

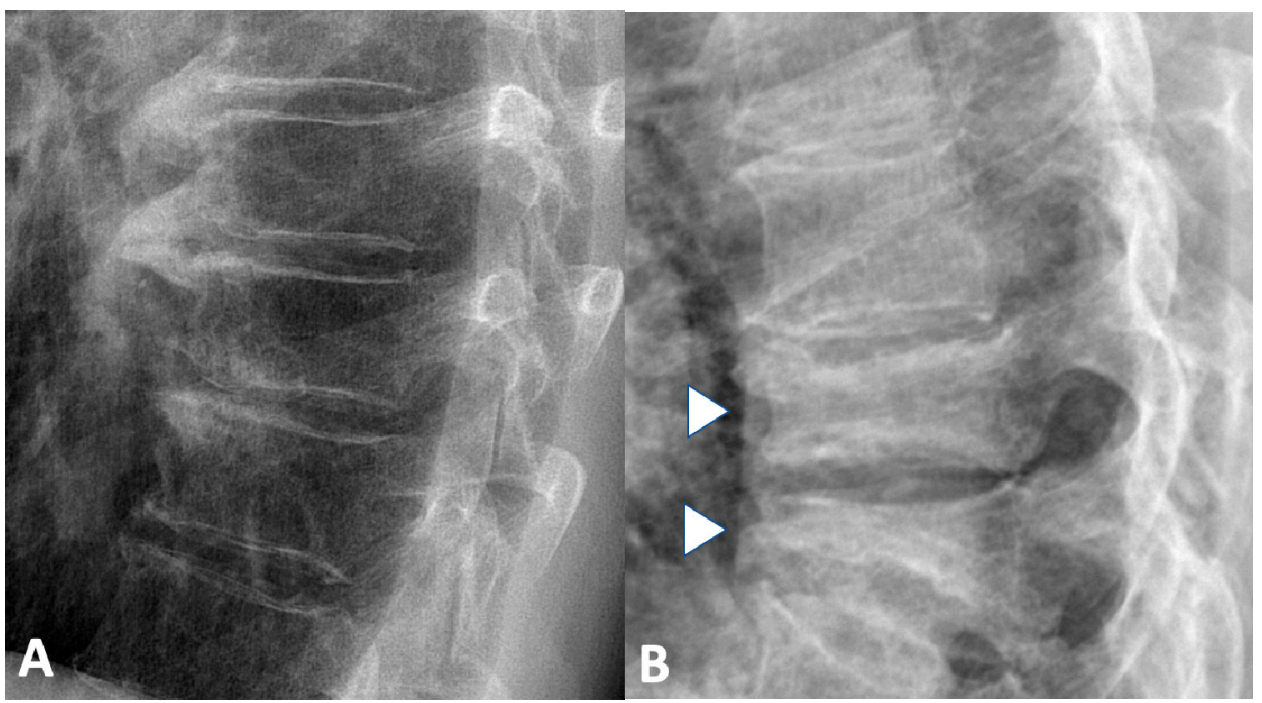

Figure 4. Conventional radiography of the spine. (A) Normal dorsal vertebrae. (B) Fracture of the 9th and 10th dorsal vertebrae (arrowheads).

\section{Conclusions}

Musculoskeletal manifestations in IBDs have a high impact on disease burden. The different imaging modalities complete the clinical examination and anamnesis, allowing a better recognition of extraintestinal manifestations. On suspicion of axial SpA involvement, besides conventional spine and pelvic radiography that can reveal late-stage structural changes, MRI is the gold standard to assess active and chronic alteration. Given that IBD patients frequently undergo MRI or CT enterography or colonography these exams could properly identify the presence of an occult SpA. When a peripheral joint, tendon, or entheseal SpA involvement is suspected, a US should be performed since it is a reliable bedside technique that allows the detection of early structural and inflammatory alterations. IBD patients have an increased risk of developing osteopenia and osteoporosis and a DEXA should therefore be carried out in order to identify and treat this non-inflammatory musculoskeletal manifestation. Finally, abdominal CT scan, often performed in IBD patients, can be used for vertebral fracture screening and assessment.

Author Contributions: Conceptualization, A.B., E.D.D. and A.A.; literature review, E.D.D., D.S. and M.R.; writing —original draft preparation, A.B., E.D.D. and G.L.; writing—review and editing, F.M., D.S. and A.A.; visualization, G.L., F.M. and D.S.; supervision, M.R. and A.A. All authors have read and agreed to the published version of the manuscript.

Funding: This research received no external funding.

Institutional Review Board Statement: Not applicable.

Informed Consent Statement: Not applicable.

Conflicts of Interest: The authors declare no conflict of interest.

\section{References}

1. Ananthakrishnan, A.N. Epidemiology and Risk Factors for IBD. Nat. Rev. Gastroenterol. Hepatol. 2015, 12, 205-217. [CrossRef] [PubMed]

2. Ribaldone, D.G.; Pellicano, R.; Actis, G.C. The gut and the inflammatory bowel diseases inside-out: Extra-intestinal manifestations. Minerva Gastroenterol Dietol. 2019, 65, 309-318. [CrossRef] 
3. Marinelli, C.; Savarino, E.; Inferrera, M.; Lorenzon, G.; Rigo, A.; Ghisa, M.; Facchin, S.; D’Incà, R.; Zingone, F. Factors Influencing Disability and Quality of Life during Treatment: A Cross-Sectional Study on IBD Patients. Gastroenterol. Res. Pract. 2019, 2019, 5354320. [CrossRef] [PubMed]

4. ACHESON, E.D. An Association between Ulcerative Colitis, Regional Enteritis, and Ankylosing Spondylitis. Q. J. Med. 1960, 29, 489-499. [PubMed]

5. Van Tubergen, A.; Weber, U. Diagnosis and Classification in Spondyloarthritis: Identifying a Chameleon. Nat. Rev. Rheumatol. 2012, 8, 253-261. [CrossRef] [PubMed]

6. Atzeni, F.; Defendenti, C.; Ditto, M.C.; Batticciotto, A.; Ventura, D.; Antivalle, M.; Ardizzone, S.; Sarzi-Puttini, P. Rheumatic Manifestations in Inflammatory Bowel Disease. Autoimmun. Rev. 2014, 13, 20-23. [CrossRef]

7. Bourikas, L.A.; Papadakis, K.A. Musculoskeletal Manifestations of Inflammatory Bowel Disease. Inflamm. Bowel Dis. 2009, 15, 1915-1924. [CrossRef]

8. Van Schaik, F.D.M.; Verhagen, M.A.M.T.; Siersema, P.D.; Oldenburg, B. High Prevalence of Low Bone Mineral Density in Patients with Inflammatory Bowel Disease in the Setting of a Peripheral Dutch Hospital. J. Crohns Colitis 2008, 2, 208-213. [CrossRef]

9. Mandl, P.; Navarro-Compán, V.; Terslev, L.; Aegerter, P.; van der Heijde, D.; D'Agostino, M.A.; Baraliakos, X.; Pedersen, S.J.; Jurik, A.G.; Naredo, E.; et al. EULAR recommendations for the use of imaging in the diagnosis and management of spondyloarthritis in clinical practice. Ann. Rheum. Dis. 2015, 74, 1327-1339. [CrossRef]

10. Bennett, P.H.; Wood, P.H.N. Population Studies of the Rheumatic Diseases. Population Studies of the Rheumatic Diseases; Excerpta Medica Foundation: Amsterdam, The Netherlands, 1968; pp. 456-457.

11. Lanna, C.C.D.; de Ferrari, M.L.A.; Rocha, S.L.; Nascimento, E.; de Carvalho, M.A.P.; da Cunha, A.S. A Cross-Sectional Study of 130 Brazilian Patients with Crohn's Disease and Ulcerative Colitis: Analysis of Articular and Ophthalmologic Manifestations. Clin. Rheumatol. 2008, 27, 503-509. [CrossRef]

12. Queiro, R.; Maiz, O.; Intxausti, J.; de Dios, J.R.; Belzunegui, J.; González, C.; Figueroa, M. Subclinical Sacroiliitis in Inflammatory Bowel Disease: A Clinical and Follow-up Study. Clin. Rheumatol. 2000, 19, 445-449. [CrossRef]

13. de Vlam, K.; Mielants, H.; Cuvelier, C.; De Keyser, F.; Veys, E.M.; De Vos, M. Spondyloarthropathy Is Underestimated in Inflammatory Bowel Disease: Prevalence and HLA Association. J. Rheumatol. 2000, 27, 2860-2865. [PubMed]

14. Peeters, H.; Vander Cruyssen, B.; Mielants, H.; de Vlam, K.; Vermeire, S.; Louis, E.; Rutgeerts, P.; Belaiche, J.; De Vos, M. Clinical and Genetic Factors Associated with Sacroiliitis in Crohn's Disease. J. Gastroenterol. Hepatol. 2007, 23, 132-137. [CrossRef]

15. Bandinelli, F.; Terenzi, R.; Giovannini, L.; Milla, M.; Genise, S.; Bagnoli, S.; Biagini, S.; Annese, V.; Matucci-Cerinic, M. Occult Radiological Sacroiliac Abnormalities in Patients with Inflammatory Bowel Disease Who Do Not Present Signs or Symptoms of Axial Spondylitis. Clin. Exp. Rheumatol. 2014, 32, 949-952. [PubMed]

16. Creemers, M.C.W. Assessment of Outcome in Ankylosing Spondylitis: An Extended Radiographic Scoring System. Ann. Rheum. Dis. 2005, 64, 127-129. [CrossRef] [PubMed]

17. Rodríguez-Reyna, T.S.; Martínez-Reyes, C.; Yamamoto-Furusho, J.K. Rheumatic Manifestations of Inflammatory Bowel Disease. World J. Gastroenterol. 2009, 15, 5517. [CrossRef]

18. Salvarani, C.; Fries, W. Clinical Features and Epidemiology of Spondyloarthritides Associated with Inflammatory Bowel Disease. World J. Gastroenterol. 2009, 15, 2449. [CrossRef]

19. Fornaciari, G.; Salvarani, C.; Beltrami, M.; Macchioni, P.; Stockbrügger, R.W.; Russel, M.G. Musculoskeletal Manifestations in Inflammatory Bowel Disease. Can. J. Gastroenterol. 2001, 15, 399-403. [CrossRef] [PubMed]

20. Sudoł-Szopińska, I.; Jurik, A.; Eshed, I.; Lennart, J.; Grainger, A.; Østergaard, M.; Klauser, A.; Cotten, A.; Wick, M.; Maas, M.; et al. Recommendations of the ESSR Arthritis Subcommittee for the Use of Magnetic Resonance Imaging in Musculoskeletal Rheumatic Diseases. Semin. Musculoskelet. Radiol. 2015, 19, 396-411. [CrossRef]

21. Lambert, R.G.W.; Bakker, P.A.C.; van der Heijde, D.; Weber, U.; Rudwaleit, M.; Hermann, K.-G.A.; Sieper, J.; Baraliakos, X.; Bennett, A.; Braun, J.; et al. Defining Active Sacroiliitis on MRI for Classification of Axial Spondyloarthritis: Update by the ASAS MRI Working Group. Ann. Rheum. Dis. 2016, 75, 1958-1963. [CrossRef]

22. Sung, S.; Kim, H.S.; Kwon, J.W. MRI Assessment of Sacroiliitis for the Diagnosis of Axial Spondyloarthropathy: Comparison of Fat-Saturated T2, STIR and Contrast-Enhanced Sequences. Br. J. Radiol. 2017, 90, 20170090. [CrossRef]

23. Leclerc-Jacob, S.; Lux, G.; Rat, A.C.; Laurent, V.; Blum, A.; Chary-Valckenaere, I.; Peyrin-Biroulet, L.; Loeuille, D. The Prevalence of Inflammatory Sacroiliitis Assessed on Magnetic Resonance Imaging of Inflammatory Bowel Disease: A Retrospective Study Performed on 186 Patients. Aliment. Pharmacol. Ther. 2014, 39, 957-962. [CrossRef]

24. Gotler, J.; Amitai, M.M.; Lidar, M.; Aharoni, D.; Flusser, G.; Eshed, I. Utilizing MR Enterography for Detection of Sacroiliitis in Patients with Inflammatory Bowel Disease: Sacroiliitis on MRE of IBD Patients. J. Magn. Reson. Imaging 2015, 42, 121-127. [CrossRef] [PubMed]

25. Bandyopadhyay, D.; Bandyopadhyay, S.; Ghosh, P.; De, A.; Bhattacharya, A.; Dhali, G.K.; Das, K. Extraintestinal Manifestations in Inflammatory Bowel Disease: Prevalence and Predictors in Indian Patients. Indian J. Gastroenterol. Off. J. Indian Soc. Gastroenterol. 2015, 34, 387-394. [CrossRef]

26. Orchard, T.R.; Holt, H.; Bradbury, L.; Hammersma, J.; Mcnally, E.; Jewell, D.P.; Wordsworth, B.P. The Prevalence, Clinical Features and Association of HLA-B27 in Sacroiliitis Associated with Established Crohn's Disease. Aliment. Pharmacol. Ther. 2009, 29, 193-197. [CrossRef] [PubMed] 
27. Mazzei, M.A.; Gentili, F.; Guerrini, S.; Di Meglio, N.; Lo Re, G.; Carotti, M.; Interlicchia, F.; Reginelli, A.; Barile, A.; Sadotti, G.; et al. Inflammatory Bowel Diseases and Coexisting Spondyloarthritis: A Neglected and Too Often Under-Reported Association by Radiologists. A Multicenter Study by Italian Research Group of Imaging in Rheumatology. Gastroenterol. Insights 2020, 11, 47-57. [CrossRef]

28. Brakenhoff, L.; Stomp, W.; van Gaalen, F.; Hommes, D.; Bloem, J.; van der Heijde, D.; Fidder, H.; Reijnierse, M. Magnetic Resonance Imaging of the Hand Joints in Patients with Inflammatory Bowel Disease and Arthralgia: A Pilot Study. Scand. J. Rheumatol. 2014, 43, 416-418. [CrossRef] [PubMed]

29. Eshed, I.; Bollow, M.; McGonagle, D.G.; Tan, A.L.; Althoff, C.E.; Asbach, P.; Hermann, K.-G.A. MRI of enthesitis of the appendicular skeleton in spondyloarthritis. Ann. Rheum. Dis. 2007, 66, 1553-1559. [CrossRef] [PubMed]

30. Geijer, M.; Sihlbom, H.; Göthlin, J.H.; Nordborg, E. The role of CT in the diagnosis of sacro-iliitis. Acta Radiol. 1998, 39, 265-268. [CrossRef]

31. McEniff, N.; Eustace, S.; McCarthy, C.; O'Malley, M.; O’Morain, C.A.; Hamilton, S. Asymptomatic Sacroiliitis in Inflammatory Bowel Disease Assessment by Computed Tomography. Clin. Imaging 1995, 19, 258-262. [CrossRef]

32. Scott, W.W.; Fishman, E.K.; Kuhlman, J.E.; Caskey, C.I.; O’Brien, J.J.; Walia, G.S.; Bayless, T.M. Computed Tomography Evaluation of the Sacroiliac Joints in Crohn Disease: Radiologic/Clinical Correlation. Skelet. Radiol. 1990, 19, 207-210. [CrossRef]

33. Hwangbo, Y.; Kim, H.J.; Park, J.S.; Ryu, K.N.; Kim, N.H.; Shim, J.; Jang, J.Y.; Dong, S.H.; Kim, B.H.; Chang, Y.W.; et al. Sacroiliitis Is Common in Crohn's Disease Patients with Perianal or Upper Gastrointestinal Involvement. Gut Liver 2010, 4, 338-344. [CrossRef] [PubMed]

34. Fauny, M.; Cohen, N.; Morizot, C.; Leclerc-Jacob, S.; Wendling, D.; Lux, G.; Laurent, V.; Blum, A.; Netter, P.; Baumann, C.; et al. Low Back Pain and Sacroiliitis on Cross-Sectional Abdominal Imaging for Axial Spondyloarthritis Diagnosis in Inflammatory Bowel Diseases. Inflamm. Intest. Dis. 2020, 5, 124-131. [CrossRef]

35. Paparo, F.; Bacigalupo, L.; Garello, I.; Biscaldi, E.; Cimmino, M.A.; Marinaro, E.; Rollandi, G.A. Crohn's Disease: Prevalence of Intestinal and Extraintestinal Manifestations Detected by Computed Tomography Enterography with Water Enema. Abdom. Imaging 2012, 37, 326-337. [CrossRef] [PubMed]

36. De Kock, I.; Hindryckx, P.; De Vos, M.; Delrue, L.; Verstraete, K.; Jans, L. Prevalence of CT Features of Axial Spondyloarthritis in Patients with Crohn's Disease. Acta Radiol. 2017, 58, 593-599. [CrossRef]

37. Kelly, O.B.; Li, N.; Smith, M.; Chan, J.; Inman, R.D.; Silverberg, M.S. The Prevalence and Clinical Associations of Subclinical Sacroiliitis in Inflammatory Bowel Disease. Inflamm. Bowel Dis. 2019, 25, 1066-1071. [CrossRef]

38. Burge, A.J.; Nwawka, O.K.; Berkowitz, J.L.; Potter, H.G. Imaging of Inflammatory Arthritis in Adults. Rheum. Dis. Clin. N. Am. 2016, 42, 561-585. [CrossRef] [PubMed]

39. Kaeley, G.S.; Bakewell, C.; Deodhar, A. The Importance of Ultrasound in Identifying and Differentiating Patients with Early Inflammatory Arthritis: A Narrative Review. Arthritis Res. Ther. 2020, 22, 1. [CrossRef] [PubMed]

40. Jeka, S.; Zuchowski, P.; Dura, M.; Zwierko, B.; Waszczak-Jeka, M. The Role of Ultrasonography in the Diagnostic Criteriafor Rheumatoid Arthritis and Monitoring Its Therapeutic Efficacy. Adv. Clin. Exp. Med. 2018, 27, 1303-1307. [CrossRef]

41. Balint, P.V. Ultrasonography of Entheseal Insertions in the Lower Limb in Spondyloarthropathy. Ann. Rheum. Dis. 2002, 61, 905-910. [CrossRef]

42. de Miguel, E.; Cobo, T.; Muñoz-Fernández, S.; Naredo, E.; Usón, J.; Acebes, J.C.; Andréu, J.L.; Martín-Mola, E. Validity of Enthesis Ultrasound Assessment in Spondyloarthropathy. Ann. Rheum. Dis. 2009, 68, 169-174. [CrossRef]

43. Bandinelli, F.; Milla, M.; Genise, S.; Giovannini, L.; Bagnoli, S.; Candelieri, A.; Collaku, L.; Biagini, S.; Cerinic, M.M. Ultrasound Discloses Entheseal Involvement in Inactive and Low Active Inflammatory Bowel Disease without Clinical Signs and Symptoms of Spondyloarthropathy. Rheumatol. Oxf. Engl. 2011, 50, 1275-1279. [CrossRef] [PubMed]

44. Rovisco, J.; Duarte, C.; Batticcioto, A.; Sarzi-Puttini, P.; Dragresshi, A.; Portela, F.; Gutierrez, M. Hidden Musculoskeletal Involvement in Inflammatory Bowel Disease: A Multicenter Ultrasound Study. BMC Musculoskelet. Disord. 2016, 17, 84. [CrossRef]

45. Bakirci Ureyen, S.; Karacaer, C.; Toka, B.; Erturk, Z.; Eminler, A.T.; Kaya, M.; Tascilar, K.; Tamer, A.; Uslan, I.; Kurum, E.; et al. Similar Subclinical Enthesitis in Celiac and Inflammatory Bowel Diseases by Ultrasound Suggests a Gut Enthesis Axis Independent of Spondyloarthropathy Spectrum. Rheumatol. Oxf. Engl. 2018, 57, 1417-1422. [CrossRef]

46. Martinis, F.; Tinazzi, I.; Bertolini, E.; Citriniti, G.; Variola, A.; Geccherle, A.; Marchetta, A.; McGonagle, D.; Macchioni, P. Clinical and Sonographic Discrimination between Fibromyalgia and Spondyloarthopathy in Inflammatory Bowel Disease with Musculoskeletal Pain. Rheumatol. Oxf. Engl. 2020, 59, 2857-2863. [CrossRef]

47. Bertolini, E.; Macchioni, P.; Rizzello, F.; Salice, M.; Vukatana, G.; Sandri, G.; Bertani, A.; Ciancio, G.; Govoni, M.; Zelante, A.; et al. Ultrasonographic and Clinical Assessment of Peripheral Enthesitis and Arthritis in an Italian Cohort of Inflammatory Bowel Disease Patients. Semin. Arthritis Rheum. 2020, 50, 436-443. [CrossRef] [PubMed]

48. Vestergaard, P. Bone Loss Associated with Gastrointestinal Disease: Prevalence and Pathogenesis. Eur. J. Gastroenterol. Hepatol. 2003, 15, 851-856. [CrossRef]

49. Cooper, C.; Atkinson, E.J.; O'Fallon, W.M.; Melton, J.L. Incidence of Clinically Diagnosed Vertebral Fractures: A Population-Based Study in Rochester, Minnesota, 1985-1989. J. Bone Miner. Res. 2009, 7, 221-227. [CrossRef] [PubMed]

50. Lisk, R.; Yeong, K. Reducing Mortality from Hip Fractures: A Systematic Quality Improvement Programme. BMJ Qual. Improv. Rep. 2014, 3, u205006.w2103. [CrossRef] [PubMed] 
51. Bartram, S.A. Mutifactorial Analysis of Risk Factors for Reduced Bone Mineral Density in Patients with Crohn's Disease. World J. Gastroenterol. 2006, 12, 5680. [CrossRef]

52. Frei, P.; Fried, M.; Hungerbühler, V.; Rammert, C.; Rousson, V.; Kullak-Ublick, G.A. Analysis of Risk Factors for Low Bone Mineral Density in Inflammatory Bowel Disease. Digestion 2006, 73, 40-46. [CrossRef] [PubMed]

53. Ezzat, Y.; Hamdy, K. The Frequency of Low Bone Mineral Density and Its Associated Risk Factors in Patients with Inflammatory Bowel Diseases. Int. J. Rheum. Dis. 2010, 13, 259-265. [CrossRef] [PubMed]

54. Bundela, R.P.S.; Ashdhir, P.; Narayan, K.S.; Jain, M.; Pokharna, R.K.; Nijhawan, S. Prevalence and Risk Factors for Low Bone Mineral Density in Ulcerative Colitis. Indian J. Gastroenterol. Off. J. Indian Soc. Gastroenterol. 2017, 36, 193-196. [CrossRef] [PubMed]

55. Reffitt, D.M.; Meenan, J.; Sanderson, J.D.; Jugdaohsingh, R.; Powell, J.J.; Thompson, R.P. Bone Density Improves with Disease Remission in Patients with Inflammatory Bowel Disease. Eur. J. Gastroenterol. Hepatol. 2003, 15, 1267-1273. [CrossRef] [PubMed]

56. Stockbrügger, R.W.; Schoon, E.J.; Bollani, S.; Mills, P.R.; Israeli, E.; Landgraf, L.; Felsenberg, D.; Ljunghall, S.; Nygard, G.; Persson, T.; et al. Discordance between the Degree of Osteopenia and the Prevalence of Spontaneous Vertebral Fractures in Crohn's Disease: OSTEOPENIA AND VERTEBRAL FRACTURES IN CROHN'S DISEASE. Aliment. Pharmacol. Ther. 2002, 16, 1519-1527. [CrossRef] [PubMed]

57. Szafors, P.; Che, H.; Barnetche, T.; Morel, J.; Gaujoux-Viala, C.; Combe, B.; Lukas, C. Risk of Fracture and Low Bone Mineral Density in Adults with Inflammatory Bowel Diseases. A Systematic Literature Review with Meta-Analysis. Osteoporos. Int. 2018, 29, 2389-2397. [CrossRef]

58. Pickhardt, P.J.; Pooler, B.D.; Lauder, T.; del Rio, A.M.; Bruce, R.J.; Binkley, N. Opportunistic Screening for Osteoporosis Using Abdominal Computed Tomography Scans Obtained for Other Indications. Ann. Intern. Med. 2013, 158, 588. [CrossRef] 